\title{
Fulfilling the Dream: The Importance of Doing What You Believe and Being Taken Seriously
}

\author{
BMES Inaugural Diversity Award and Lecture: BMES Annual Meeting, October 10, 2009
}

\author{
Sheldon Weinbaum \\ Department of Biomedical Engineering, Grove School of Engineering, The City College of New York, \\ New York, NY, USA
}

(Received 22 December 2009; accepted 25 December 2009; published online 9 January 2010)

\begin{abstract}
In this Inaugural Diversity Lecture I trace the diversity struggles in my own life over the past 46 years since the historic 1963 "I Have a Dream" speech of Martin Luther King, which has changed this nation forever. After a brief personal history, the paper is divided into three major parts; "My consciousness raising years", "Fulfilling the dream", and NIH Minority Scholars Program. The paper ends with some concluding thoughts on the importance of being taken seriously.
\end{abstract}

Keywords-Diversity in biomedical engineering, Teaching, Civil rights.

\section{INTRODUCTION}

On August 28, 1963 my wife and her best friend boarded a bus with a Black church congregation in

\footnotetext{
Address correspondence to Sheldon Weinbaum, Department of Biomedical Engineering, Grove School of Engineering, The City College of New York, New York, NY, USA. Electronic mail: weinbaum@ccny.cuny.edu

CUNY Distinguished Research Professor Sheldon Weinbaum received his BAE degree from RPI in 1959, his MS degree in Applied Physics from Harvard in 1960 and his PhD degree in Engineering in 1963, also from Harvard. In the early part of his career he was widely recognized for his contributions to re-entry aerodynamics and basic studies in fluid mechanics nearly 40 of which have been published in the Journal Fluid Mechanics. Starting in the early 1970s he shifted his interest to transport and cellular level biomechanical phenomena in the human body. He is widely recognized for the Weinbaum-Jij equation for microvascular heat transfer, his discovery with Shu Chien of the endothelial pore for the entry of LDL cholesterol, his studies with S. Cowin and M. Schaffler on fluid flow and mechanotransduction in bone, his studies on the role of the endothelial glycocalyx in mechanotransduction and microvascular fluid exchange and the role of brush border microvilli in glomerulo tubular balance. Most recently he has proposed a new hypothesis for vulnerable plaque rupture and a new concept for an airborne jet train that flies on a soft porous track within $\mathrm{cm}$ of the earth's surface at speeds approaching jet aircraft with $1 / 5$ their fuel consumption. He is one of eight living individuals elected to all three U.S. National Academies and is the only engineer to have received a Guggenheim in the area of cell and molecular biology.
}

Philadelphia to participate in the civil demonstration in which Martin Luther King gave his "I Have a Dream", a speech which has changed this nation forever. I am sorry to say that I was not on that bus. Four years earlier I had graduated from RPI, the nation's oldest engineering school. I was one of 870 graduates. To the best of my knowledge there was only one female in our graduating class, Sandy Gibbons. Today the President of this same institution is an AfricanAmerican woman, Shirley Ann Jackson, and 31\% of the 2009 freshman entering class is female. Dr. Martin Luther King would probably never have dreamed that only 45 years after his momentous speech the nation would have elected its first Black President. Yet despite these enormous changes higher education is still permeated with racial and gender inequities that are much more subtle, inequities that deprive us of fulfilling the dream that was so elegantly presented on that August afternoon. Underrepresented minority students (URMs) represent $34 \%$ of 18-24 year olds, but only $12 \%$ of the BS degree recipients in engineering and only $3 \%$ of the PhDs. In BME, URMs constitute an even lower $8 \%$ of BS recipients. The situation for women appears to be much better in that women comprise $40 \%$ of all BS degree recipients and about $35 \%$ of $\mathrm{PhD}$ recipients. However, for more complex reasons this is not reflected in faculty at ASEE institutions where their representation is only $18 \%$ or roughly half of what one would expect is the available pool. This is not only true for BME but nearly all science and engineering disciplines.

In this Inaugural Diversity Lecture I trace the diversity struggles in my own life over the past 46 years since that historic moment. After a brief personal history, the paper is divided into three major parts with subsections, starting first with what I call my consciousness raising years. The second part is called 
Fulfilling the dream and the third part is entitled NIH Minority Scholars Program. The paper ends with some concluding thoughts on the importance of being taken seriously. To help the reader, a short summary is given below to provide a chronological map of the key events in the sequence that they occurred in connecting parts one through three.

I received my $\mathrm{PhD}$ the same summer as Dr. King's historic speech. The following year, 1964, I was fired from my own first full time position in industry for being too outspoken on employment and diversity issues. Four years later I was almost canned within a year of my arrival at The City College of New York for my role in the 1968 Black and Hispanic student takeover of the CCNY campus during the CUNY "Open Admissions" struggle, the takeover nearly coinciding with MLK's death. There have been numerous other struggles since then, including ending free tuition in 1976 when Black and Hispanic students were admitted for the first time in large numbers to CUNY. From 1976 to 1985 I was the faculty advisor to the Society for Women Engineers since there were no female engineering faculty. Our main project was the recruitment of female and URMs in inner city high schools. The large increases in state mandated tuition in the early 1990s led to a widely publicized lawsuit (Weinbaum vs. Cuomo) in 1992 in which 250 faculty and students charged New York State officials with racial discrimination in funding of CUNY's senior colleges. The establishment of the New York Center for Biomedical Engineering (NYCBE) in 1994, a research consortium with medical research institutions in the Big Apple, and the creation of CCNY's own BME Department in 2002 provided an unusual opportunity to create a department with a new educational vision that was centered for the first time equally on diversity and excellence. This vision was nourished initially by three Whitaker "Special Opportunity Awards" and more recently by a challenge grant from the Wallace Coulter Foundation and a diversity grant from NIH for minority undergraduate education in the life sciences. The latter grant, which was intended to create a national urban model for diversity in education in the life sciences, has transformed the BME Department. It has integrated undergraduate and graduate students and brought large numbers of high achieving URM students (NIH minority scholars) into faculty laboratories creating a sense of family and caring. Sixty percent of our NIH scholars pursue a $\mathrm{PhD}$ or MD after graduation. This in turn has established an atmosphere which is highly appealing to women and URM faculty recruits. Currently, to the best of my knowledge, we are the only research oriented science and engineering department nationally where one half of the tenure track faculty are female and/or URM.

\section{My Family Background in Diversity}

There was very little in the first 25 years of my life that would have led anyone to suspect I would become active in diversity issues later in life or inspire others to do so. I was born of middle-class Jewish parents, who took little active interest in the civil rights movement. My mother came from a poor immigrant family from a small Jewish town in Poland. She grew up on the lower East Side of Manhattan and then the Bronx and all four children went to work at a very early age. It was and still is remarkable to me that she skipped four grades in grammar school and finished her public education at the age of eleven. She then went to business school for a year and a half to learn bookkeeping and entered the work force before her 13th birthday. At the age of 16 she was in charge of the bookkeeping section of a jewelry company large enough to be on the New York Stock Exchange. When I think of Sandy Gibbons, I invariably think of my mother and what she would have done if she had been born later and under different circumstances. My father was an immigrant from the Ukraine who arrived in the U.S. in 1920 , the son of a wine merchant, as my name would suggest. He studied metallurgy at Polytechnic University in Brooklyn since his brothers were in the dental business and interested in refining old gold from sweepings in the laboratories of dental technicians. He went into his own dental business during WW II. He was a soft touch when it came to collecting his accounts receivable and the business folded the year before I went off to RPI, fortunately on a full scholarship. This was a very hard time for the family. I, my younger brother, Paul, and our parents shared a small one-bedroom apartment close to the Brooklyn anchorage of what is now the Verrazano Bridge.

In 1961 I met my future wife, Alexandra (Sandy) Wolkowicz, unfortunately the week before my father died. We would have been married sooner, but by Jewish custom one has to wait a year after a parent has died. Sandy was from a professional (doctor's) family with socialist leanings and one of the most articulate people I had ever met. She was a junior at Smith College and an outspoken advocate for civil rights. It was hardly a surprise that she would be at the reflecting pool to hear Dr. King's historic speech. I think of our meeting as the most fortunate thing that ever happened to me. I can only claim that I had great susceptibility to consciousness-raising, but Sandy was a remarkable mentor. As a 10-year old from Brooklyn I had lived and breathed the Jackie Robinson Dodgers and my hero was Pee Wee Reese, their captain, a southerner who was wise enough to do the right thing when Robinson was receiving death threats. Growing up in a nearly all Jewish neighborhood in Brooklyn, it was my 
first conscious realization of the bitter race history of this country. There is now a statue of Jackie and Pee Wee arm in arm in front of the Brooklyn Cyclones Stadium in Coney Island and three pictures showing this remarkable friendship sitting above my desk.

\section{PART I: MY CONSCIOUSNESS-RAISING YEARS}

\section{My Brief Experience in Industry 1963-1967}

I see the period from 1963 to 1976 as my consciousness raising years. In 1963, shortly before Dr. King's speech, I had graduated from Harvard and was offered a junior faculty position at a salary of $\$ 8400$ per annum, but instead took a position at the new Sperry Rand Research Laboratory in Sudbury at nearly double the salary. It was the last time I ever took a position for money. It made little difference since I was fired within a year for what can best be described as insubordination. The mother company Sperry had a prior history of anti-Semitic hiring practices and to the best of my memory the professional staff was exclusively white and male. When I went to the Director of the Laboratory to express my concern about their hiring practices, I was told that he was sorry that I felt that way and was given two weeks severance pay.

My next two industry experiences were far superior. It was the Sputnick era and aerospace was the rage. After a brief stint at the Avco Everett Research Laboratory, I took a position at the GE Space Sciences laboratory in Valley Forge where I was seen as a model employee, quite a change from my days at Sperry. I had developed a theory for the laminar wake of a missile at high altitude, referred to later as the Weinbaum-Weiss model of the near wake, and was nominated by the GE Missile and Space Division as their candidate for the "Man of the Year" Award by the Pennsylvania Junior Chamber of Commerce. Women were not even on the radar scope. My co-winner was Anthony G. Amsterdam, a human rights hero in every sense of the word, and a rising star at the University of Pennsylvania Law School. He fought against capital punishment, was a defender of journalistic freedom and at the center of the civil rights struggle. It was an honor to even be on the same dais and it did make me wonder for the first time whether I could be doing better things with my life than just science. My days at GE were also numbered. Both Sandy and I were growing more and more concerned about the atrocities in Vietnam and by the spring of 1967 I felt I could no longer work in aerospace, even from a defensive perspective of detecting missiles, and that I needed to return to academia. I took a $40 \%$ pay cut, returned my grants to the federal government and in the fall of 1967 arrived at the doorsteps of The City College, once again eschewing an offer from an Ivy League institution. It turned out to be one of the wisest decisions in my life, although my reasons for coming to the College were far different than the reasons I have stayed all these years.

\section{My Early Years at City College 1967-1976}

In 1967 CCNY's School of Engineering (SOE) was a nearly all white institution without a single tenure track female faculty member. However, the College did have a special kinship to my own experience of growing up in New York. In 1847 it was founded as the first free academy of higher education in the Unites States, and when I arrived often referred to as the "poor man's" Harvard with one in every nine of its undergraduates going on for PhD's and more Nobel laureates from its undergraduate alumni (ten) than any public institution in the world. First and foremost in my mind was that it was free. Uncles on both sides of my family had attended, although my brother Paul was the first to complete a degree. My son Daniel would later also graduate from CCNY in 1995. It was the school of the economically disadvantaged and immigrants, but certainly at the time not the college that welcomed people of color. The CUNY Graduate School had just been founded and I thought in no time at all CCNY would become the Berkeley of the East Coast.

Except for the SOE, most of the faculty at CCNY were very liberal, many involved in the anti-war movement of the 1960s. I quickly found myself in trouble. The dean of the SOE had been a colonel in the Army Core of Engineers and a supporter of the war effort. When the Marine Corp and Dow Chemical (manufacturers of Agent Orange) were recruiting in the lobby of Steinman Hall, the engineering building, I went to the dean and asked for a "peace table" next to them. I was soon organizing student anti-war demonstrations in the building. Shortly after that I had a brief conversation with the dean on the plaza in front of Steinman Hall. He suggested that I put my pension money in TIAA-CREF rather than TRS, the NYC Teachers Retirement Service, since I would be able to take it with me. I had been fired in industry, but never thought this could happen to me in academia. Aside from the war, even more serious problems for the College were on the horizon.

The City College rests on a hill in the middle of Harlem. It is the flagship and founding college of the CUNY system. In 1969 the combined Black and Hispanic undergraduate enrollment at the College was only $6 \%$. In April and May of that year a struggle 
erupted at the CCNY campus which quickly spread to nearly all the other colleges of CUNY. Black and Hispanic students had seized and closed down the entire campus except for the SOE, which through the efforts of its dean had remained open and continued classes. The student rebellion, now referred to as the "Open Admissions Struggle", was long overdue. Black and Hispanic students demanded greater access to CUNY. Three faculty; two sympathetic to student demands, were appointed as negotiators with the occupying students who threatened community demonstrations unless the SOE would also close. As the only easily recognized outspoken sympathizer among engineering faculty, I was contacted by the two sympathetic negotiators and asked if I could help organize a meeting of the SOE faculty to discuss its closing. Only the dean could call such a meeting and it was obvious that he would never agree. I agreed to take on this foreboding task, knowing full well, not having tenure, that this could be an abrupt end to my stay at CCNY. It surprises me to this day how little fear I had at that moment. Once you have been fired and have lived through its repercussions the fear of it happening again is greatly diminished. I called each of the department chairs, arranged for the large lecture hall without ever informing the dean, and at 9 AM the next Monday morning we had a record attendance at an unofficial SOE meeting. To my amazement I was not fired, but censored by the SOE faculty at their next official meeting, but fate was not so kind to the more radical of the two faculty negotiators, who was subsequently asked to leave.

Two other events played a crucial role in my consciousness raising. Sandy and I had purchased a brownstone in Park Slope Brooklyn. This middle class, but politically active community was one of the major centers of the women's movement in NYC. In 1970 we already had two children, Alys and Daniel, and Sandy was having a very difficult time completing her $\mathrm{PhD}$ in history at Columbia, since she had by far the primary responsibility for our children. The entire neighborhood was filled with women's consciousness raising groups. I was very sympathetic and decided to organize a men's group who were open to the basic tenets of the women's movement. Our group received some notoriety because there were few such men's groups and a front page story appeared in the Village Voice entitled "Husband Dumping in Park Slope" written by the wife of one of our members. Of the nine initial members, I was the only one whose marriage survived this tumultuous period. More to the point, I made a more concerted effort to finally try and share the huge responsibility of child raising. For 1 year I stayed home from school one day a week to take care of a group of 2 year olds in a shared arrangement with four other families. Most nursery schools at the time started at the age of three. This irked some of my more conservative faculty in the department who were annoyed that they could not have department meetings on my child care days. It led to my understanding of how difficult it is to share parenthood and the huge burden that many women faculty with children face.

The culminating experience in my consciousness raising came in 1976, when New York City went bankrupt. After "Open Admissions" was instituted in 1970 enrollment at CUNY mushroomed to 275,000 . The City could no longer support its senior colleges and they were taken over by the state in a 7-year transition. Free tuition was abolished after 129 years, and the City was placed under the control of an Emergency Financial Control Board (EFCB). What had been voted in by public plebiscite in 1847 was removed in the wink of an eye without any public input. As a URM student so aptly expressed to the NY Times "as soon as Black and Hispanic students showed up to the dinner table in large numbers the meals were no longer free." Students and faculty were furious. I went down to the EFCB to get arrested but there were so many ahead of me that I was never able to get in. I was very disheartened. It was the first and only time that I though I might leave CCNY. Shortly thereafter, I received a phone call from an Ivy League Institution asking if I would consider being a department chair with a $50 \%$ increase in salary and free college tuition for my two kids. I went upstairs to talk with Sandy in a conversation that lasted all of two minutes. Sandy had grown to love New York and its diversity and I realized I had a new mission, to try and transform CCNY so that it could live up to its founding motto to "educate the children of all the people." My die had been cast. In the preamble to the enacting legislation for the state takeover of the CUNY senior colleges Governor Hugh Carey pledged that it was his vision that the state's two great public universities, CUNY and SUNY, would as quickly as possible be funded and treated equally. This was a promise that was not to be kept.

\section{PART II: FULFILLING THE DREAM}

\section{First Efforts to Diversify the Undergraduate Student Body in the SOE}

By 1976 CCNY as a whole had a student population that was not far from what it is today, $55 \%$ Black and Hispanic, 25\% Asian and 20\% white. This diversity was unique among colleges in the United States and reflected the demographics of New York City. This was not true of the SOE because of the math and science admission requirements and the gender balance 
was overwhelming male. In 1976 I took on the role of faculty advisor to the newly formed student chapter of the Society of Women Engineers because in a tenured faculty of 125 there was not a single female. I was mentored in this role by Eleanor Baum, a former alumnus, and first female dean of an engineering school in the U.S., who at the time was at Cooper Union. The main function of our student chapter was to visit and recruit women and URM students from the public high schools in NYC. Over the next 10 years I, and my student group, made over 90 such visits. In 1985 the SOE hired Carol Steiner, its first tenure track female faculty member since Cecilia Froehlich, a German Jewish émigré and friend of Eleanor Roosevelt who taught at the college after WW II. The leadership of SWE passed to Carol.

To enhance the above effort I went in the spring of 1977 to see CCNY President Robert Marshak, the noted physicist, and asked if he would give me $\$ 5000$ to start the first summer outreach program for students from inner city high schools, who were interested in science and engineering. The money paid for transportation, lunches and a small stipend since many of the students would normally try to get jobs during the summer. The students helped graduate students in the college laboratories and heard lectures on various careers in the sciences and engineering. This effort turned out to be highly successful and in short order was greatly expanded by other faculty at CCNY and the other CUNY colleges.

\section{First Efforts to Diversify the Faculty in the SOE}

1986 and 1987 were a major transition at the SOE. While the above efforts significantly helped diversify the student body in the SOE, the faculty did not reflect this diversity nor did my own graduate students. Up until 1987 I had mentored $19 \mathrm{PhD}$ students, all male, though one was African-American. This former student, Ghebre Tzghai, is now Associate Director of Global Health Care Research for Procter and Gamble and inventor of the first tarter control toothpaste and several deodorants. By chance the SOE was searching for a new dean in the spring of 1986. I realized that this was a golden opportunity to recruit a URM dean with a commitment to diversifying our faculty. The department chairs initially had appointed themselves as the search committee, but there was a faculty revolt and by vote a decision was made to choose faculty who had the greatest external recognition for their research. Having been just appointed CUNY Distinguished Professor, I was selected and the committee chose me as their chair. Few thought there would be a significant pool of qualified URM candidates. With the help of Heywood Burns, founder of CCNY's Urban Legal
Studies Program and later first Dean of the new CUNY Law School, and other Black colleagues outside CUNY, 13 qualified URM candidates were identified. Charles Watkins was selected as the first African-American Dean of an engineering school in the U.S. outside the HBCUs. Dean Watkins had been chair of ME at Howard University and was the driving force behind the first engineering $\mathrm{PhD}$ program established at a HBCU.

\section{My Search for Female Graduate Students}

My failure to have any female $\mathrm{PhD}$ students in my first 20 years at CCNY was an embarrassment having both a spouse and daughter who are ardent feminists. It was something I knew I had to correct, but in my 20 years in ME at the time the department had not had a single female $\mathrm{PhD}$ student. I had been to China in 1983 as part of the first U.S.-China-Japan (now includes Singapore) Conference in Biomechanics and realized that there were a fair number of female graduate students in ME, many near the top of their class. On my next sabbatical in 1987 I spent a month visiting the top Chinese institutions and letting their faculty know that I was especially interested in women wishing to pursue the $\mathrm{PhD}$. The first of these recruits is known to many of you, Professor Bingmei Fu. In the 22 years since then I have had $26 \mathrm{PhD}$ students and 16 have been women. Initially, all my female $\mathrm{PhD}$ students were from China, but in the past decade with the establishment of many BME programs nationally this has greatly changed.

\section{A Nice Surprise}

In 1988 something entirely unexpected happened. There are 300,000 public service employees in NYC and every year The Fund for the City of New York chooses six to receive from the Mayor the Public Service Award for NYC. A friend asked if she could nominate me and to my amazement I became the first CUNY faculty recipient of this award. The tribute that appeared in the NY Times 12/13/88 under my picture said "for his role in helping making the college the largest source of minority engineering graduates in the country." In truth there were many faculty who contributed to this honor. CCNY no longer holds this distinction because many schools have recruited URM students and a number of these institutions have far larger total engineering enrollments. Nevertheless, the newly named Grove School of Engineering (after Andrew Grove co-founder of Intel) is still one of only a few schools of engineering identified as a minority serving institution with roughly $50 \%$ of its undergraduates URMs. In 2009 the Fund for the City of New York with the 
support of the Sloan Foundation instituted a new award to honor outstanding science, and math faculty in the NYC public high schools. I have had the honor of being asked to serve as the first chair of the selection committee.

\section{Weinbaum-Cuomo Civil Rights Lawsuit 1992-1996}

The recession of 1990-1992 had a major impact on New York State. Governor Cuomo had nearly doubled the tuition at CUNY and SUNY over a 2-year time span and many of the CUNY students were particularly hard hit. CCNY was again the lead CUNY institution in a series of campus takeovers. My son Daniel's participation in the CCNY takeover sensitized me to the dissatisfaction of many of our students. Also the State Legislature had never honored the promise made by Governor Carey that CUNY and SUNY would be funded equally. In spring 1992 I attended the FASEB meeting in Atlanta with the idea in mind that I would also visit Habitat for Humanity to see if I could get former President Carter to be a commencement speaker. In the waiting room there was a copy of USA Today in which there was a special feature on the U.S. Supreme Court case pending that summer against the University of Mississippi. Thirty years after James Meredith had integrated "Ole Miss" the undergraduate student body was still only $9 \%$ Black, whereas Jackson State, a HBCU, was 93\% Black and received funding per student that fell $12 \%$ short of that of "Ole Miss" though both were $\mathrm{PhD}$ granting institutions. Intuitively, I knew that the same was true in supposedly liberal New York State where at the time the senior colleges of CUNY were $54 \%$ students of color, whereas the SUNY senior colleges were $90 \%$ white. With the community colleges included CUNY was two-thirds Black and Hispanic whereas SUNY was $85 \%$ white. The alleged difference in funding per student was nearly the same as in Mississippi. In addition, my research indicated that state financial support for graduate students at SUNY was six times that at CUNY. The alleged difference in state funding between CCNY and SUNY Stony Brook, the major science campuses of both systems, was close to $25 \%$ per student.

I went armed with these statistics to present Governor David Paterson, who at the time was leader of the Black and Hispanic Caucus in the State Legislature. I asked him if he was aware of these inequities to which he replied that of course he was and then added that his supporters were far too few to do anything about it. Governor Paterson wrote an article for New York Newsday that weekend using my data on ethnicity, student support and enrollment and encouraged me to seek legal action. I studied the details of the
Mississippi case in the Brooklyn Law School library and drafted the outline of a brief with five principal charges. This draft was brought to the Center for Constitutional Rights, a well known progressive civil rights law firm in New York and the case was taken on pro bono. The lead lawyer assigned to the case initially was Franklin Siegel, and was later transferred to Frank Deale when Siegel left for private practice. The preparation of the lawsuit required major organizational details including the solicitation of student and faculty plaintiffs from all the senior colleges, the CUNY Graduate School and several of the larger community colleges. A CUNY Legal action Committee was formed headed by me and a dear friend, Camille Rodriquez, who I had recently met at $3 \mathrm{AM}$ in the morning when we both responded to a call for faculty to witness the NYC police arrest of CUNY students at New York City Technical College in a student takeover to protest the huge tuition increase.

The lawsuit was announced on 2/26/92 and the next morning the four column lead story in the Metro Section of the NY Times read " 250 at CUNY Sue New York Citing Racial Bias in Budget." The case was carried by news media all over the nation since tactics that had previously been used only in the South were now applied for the first time in a liberal northern state. At the time most of the federal judges were Reagan appointees and lawyers brought the case to state court. In the end this proved to be a mistake since in federal court one has to only demonstrate impact whereas in state court one has to show intent to discriminate. The legal battle lasted for 4 years, with the lower courts ruling in favor of the plaintiffs, but the ruling was eventually overturned in 1996 in the State Court of Appeals on the grounds that the State did not have to fund its two university systems equally provided students were provided with equal access to both institutions. The decision was a travesty in that most of the Black and Hispanic students in NYC could not afford to live away from home in dormitories, and CUNY was their only choice. It was a lesson for me in civil rights jurisprudence. The one positive effect was that initially, at least, the subsequent state cuts to higher education were equitably administered to CUNY and SUNY.

\section{Sloan Grants for PhD Education for URMs}

The disappointment over the lawsuit made me channel my efforts in a new direction. By far the largest inequity mentioned in the Introduction is the percentage of URMs who pursue the PhD in engineering compared to their available pool. While URMs comprise $12 \%$ of the BS degree holders in engineering they are only $3 \%$ of $\mathrm{PhD}$ degree recipients. Changing this 
has been my major focus over the past dozen years. CUNY's PhD program in BME was first established in 1999 as part of the second of our three Whitaker Special Opportunity awards. With the assistance and encouragement of Dean Watkins, I approached the Sloan Foundation with a new idea that I thought might significantly enhance the likelihood that high achieving URMs might choose to go on for a PhD. Since many of these students come from economically deprived families, the lure of a well paying job after receiving a BS is an attraction for many hard to turn down.

Normally there is little personal contact between a student's undergraduate and graduate teachers since students are usually encouraged to go to graduate school other than at their Bachelor institution. Furthermore, students from low income families at CCNY often do not feel comfortable leaving their family and applying to the rich, top ranked BME programs. I wondered if this trend could be significantly changed if the process was facilitated by direct contact between myself and Professor Stephen Cowin and our personal faculty colleagues at these top tier institutions. Four institutions were chosen from the top ten NRC ranked programs nationally: Duke, Hopkins, University of Pennsylvania, and UCSD. Five students would be sent for a summer research experience at the end of their junior year to one of these four programs. All living expenses were paid and the students received a significant stipend that was comparable to summer employment. The Sloan Scholars program, which was first funded in 1997 and renewed in 2001, worked well in that $50 \%$ of these Scholars did go on for PhD's, but most of these students chose to stay on at CUNY rather than one of our four partner institution, especially after our own BME PhD program was started in 1999, so they could be in closer touch with their families.

\section{Creation of the BME Department and Its Vision}

The BME program at CCNY had initially started in 1994 with the support of a first Whitaker "Special Opportunity" award as a 12 credit an inter-departmental concentration at the undergraduate level with a research arm called the New York Center for Biomedical Engineering, an unofficial consortium of major medical research centers in NYC. The two original medical partners, the Hospital for Special Surgery and the Hospital for Joint Diseases at NYU, have since greatly expanded to include eight of the premier health care centers in the City. Well over two hundred students, undergraduate and graduate, have since worked in the laboratories of our hospital partners. The birth of a full fledged BME Department in 2002 with the support of a third Whitaker "Special Opportunity" award provided an opportunity to create a department with a unique vision that placed equal emphasis on excellence and diversity. The four founding members were myself and CUNY Distinguished Professor, Steve Cowin, and two junior faculty, Susannah Fritton and Maribel Vazquez. These four were supplemented by over 30 faculty from the NYCBE and CCNY faculty with BME interests in $\mathrm{ChE}, \mathrm{EE}$ and $\mathrm{ME}$.

It was my dream from the start that the following would happen: (1) the faculty would reflect the racial and gender diversity of the undergraduate program. Currently, six of the twelve tenure track faculty are female or URM. To the best of my knowledge it is the only ranked program in the sciences and engineering nationally where $50 \%$ of the tenure track faculty are female or URM, (2) the program would also place a special emphasis on encouraging high achieving URM students to pursue the $\mathrm{PhD} / \mathrm{MD}$ degree and create a sense of family between faculty, graduate students and undergraduates by building communal research and mentoring experiences, and (3) that the expectations for performance of faculty judged by the merit based metrics of publications, citations and funding be on a par with the top programs nationally. Currently, the faculty average five journal publications, over 200 citations and funding of $\$ 400,000$ per year per faculty member. The NIH minority scholars program, which I describe next, has played a vital role in these achievements since it involves virtually every PhD student and faculty member in the department.

\section{PART III: NIH MINORITY SCHOLARS PROGRAM}

In 2001 the National Heart, Lung and Blood Institute of NIH started a new program for minority undergraduate education in any field of the life sciences. The purpose of the grant was to encourage URMs to pursue the PhD in a life science field. With the encouragement and support of Dr. Laurent Mars, student Administrative Director of the New York Center for Biomedical Engineering (NYCBE), we applied for this grant and were one of two institutions nationally to receive the award. The grant was renewed in 2006 for an additional 5 years. The grant has had a major transformative effect on the entire BME Department and is given its own section since it serves as a national model for what is possible.

The NIH Minority Scholars Program is funded at a level of $\$ 500,000 / y r$. It provides full tuition, a $\$ 6000$ annual stipend so that students do not have to work after school (CCNY is a commuting campus where $70 \%$ of the student body work part time), and $\$ 4000$ for each summer research experience. It supports 20 25 URM students/year (2/3 BME majors and 1/3 BME 
concentrators with majors in ChE, EE, and ME). All students are required to spend at least $8 \mathrm{~h} /$ week on $\mathrm{BME}$ research projects in both their junior and senior years in addition to their regular course load and complete at least one summer of research. They receive up to $\$ 4000$ in research supplies and travel/yr to attend professional meetings. Every student has a personal paid $\mathrm{PhD}$ student mentor who meets with him/her at least one $\mathrm{hr} / \mathrm{wk}$ and there are paid teaching assistants (TAs) available for all BME students in critical courses where students have difficulty. Scholars must maintain a GPA $>3.0$ or are dropped after one semester for not meeting this GPA. Since the start of the program each class of graduating NIH Scholars has maintained an average GPA of 3.5 or better. They are the highest performing group in the BME Department creating a new paradigm demonstrating that with proper support and encouragement URM students can be the best performers.

The NIH Minority Scholars Program differs from other related enhancement programs, such as the widely recognized Meyerhoff program at University of Maryland Baltimore County, in that it is applied within a single department, places a very high emphasis on hands-on research, and includes a new component, a personal $\mathrm{PhD}$ student mentor for guidance and encouragement. The latter has turned out to be the single most important innovation. Starting in 2006 the program hired an exceptional external evaluator, Dr. Mia Ong, Director at that time of the Harvard Civil Rights Project. Dr. Ong spends two full days every year interviewing scholars, mentors, TAs and all faculty and staff closely related to the program including the Dean of the Grove School of Engineering. All quotes herein are obtained from Dr. Ong's 2009 detailed annual report. Each report identifies problem areas and makes constructive suggestions for improvement. There is also a very dedicated and experienced Student Administrative Director, Dr. Phillip Payton, who oversees the dayto-day operation of the program in addition to other BME Department duties. Dr. Payton is also an aspiring Black minister in one of his roles outside the college.

The annual retention rate for all students (freshman through seniors) from 2002 to 2006 was $23 / 33$ or $70 \%$. Students leave the program largely to change major or because they have not met the GPA > 3.0 requirement. This retention was disappointing, though it was nearly $30 \%$ higher than the rest of the SOE. Most dropouts occur in the first 2 years. In 2006-2007 the idea of a personal $\mathrm{PhD}$ mentor and TAs for critical courses was first tried. The results were dramatic. The retention rate for 2007-2009 increased to $47 / 50$ or $94 \%$. A few key quotes from scholars, mentors and TAs provide important insight into the importance of the mentorship program.
I was really taken aback, because everything that's offered, all the help and advice and motivation and the pushing and everyone's just willing to be there, like, for you. It lets me know that I'm not in this college process alone. [Scholar]

There is a special experience to this [program]. There are help networks, support groups... They can come talk to us. I don't know how you can call that-family, extended family. It's a good feeling. [NIH Teaching Fellow]

I'm pretty much sure [my Mentee's] learning a lot from me, but at the same time, I'm deeply affected by this mentorship. First of all, I realize, I make sure I'm helping somebody. Whatever I say to him may affect his future. The thing is, if somebody trusts you, chances are, you're working a little bit harder than ever to improve yourself, to be a better person. [NIH Mentor]

One hundred percent of scholars responded positively to the statement my mentor has helped me with other personal or academic issues not directly related to the BME program. This varied from personal study habits, to application for graduate school and internships, to simply having an older friend who was one full step ahead in the educational process to ease the anxiety of becoming a graduate student. Ever since the mentor and TA program was started there has been a waiting list of $\mathrm{PhD}$ students to participate in one capacity or the other. $38 / 63$ or $60 \%$ of the scholars over the past 3 years have said they planned to go on for a $\mathrm{PhD}$ or MD.

Another helpful insight came from Dean Joseph Barba. Dean Barba who attributed the Department's success to departmental leadership (John Tarbell has been chair since 2005) and a "trickle-down" model of mentoring:

BME is perhaps the most student-centered program, undergraduate and graduate. The senior members mentor the junior faculty. And together, they augment the graduate students and undergraduate students. I think it's a successful model. I don't think anybody in the school does it as well as they do.

Another practice among the senior faculty in the BME Department is that they have continued to foreground diversity in their vision of departmental development and strength. Dean Barba noted:

In terms of the faculty they're attracting, they're very conscious to bring women in, trying to bring 
in underrepresented people in engineering.

They're building very strong research groups.

A key component of the NIH Minority Scholars Program is a Research Day every semester when junior and senior Scholars are given 15 minutes to present their research. Freshman and sophomores are also required to attend to see what will be expected of them when they start their research as juniors. The following two quotes provide evidence of the importance of this component of the program:

The research experience was so great because I learned so many things that I didn't learn in any class. I was able to have experiences doing experiments in the lab and getting information by myself. Learning to look up references. It kind of helped me for the classes. [NIH Scholar]

Research, research, research. I wouldn't be in an $\mathrm{MD} / \mathrm{PhD}$ program right now if it weren't for it. Thanks! [NIH Scholar]

\section{CONCLUDING THOUGHTS: THE IMPORTANCE OF BEING TAKEN SERIOUSLY}

Despite the very obvious progress toward gender diversity that has been made in BME, and much less so racial diversity, there is a huge gap between the achievements of women and URMs and the recognition that they receive. I attribute this to the importance of being taken seriously and, in many cases, not intentional bias. This starts at the highest level, membership in our Academies and Fellows of our Society. In 2000 Frances Arnold became the first women elected to the Bioengineering Section of the NAE. There were 69 male members at the time.

Every year after my own earlier election I would volunteer to be on the Peer Committee for the selection of new candidates for the Section without success. Every year I would bring up the issue of diversity at the Annual Meeting. In 2003 I was finally given a chance to serve. In my first year on the Committee I volunteered to prepare a list of potential female and URM candidates who I thought either now or in the future deserved closer attention. This list contained a shocking 55 such individuals. I persuaded the rest of the Peer Committee to do a mailing to the entire Section membership in which members were asked if they were acquainted with the qualifications of the individual to indicate whether they were well qualified, qualified or not qualified for membership. This survey readily identified the most promising candidates, but more importantly also the individuals whom I could approach to prepare a nomination especially if they had indicated well qualified. Every year since 2004 a woman has been elected. Furthermore, since then there has always been a woman on the Peer Committee. This year Frances Ligler succeeded me as first female Chair of the Section. There are clearly very promising younger woman candidates whose qualifications compare well with male candidates a decade their senior whose qualifications had not previously been taken seriously.

In our own Society there are currently 112 BMES Fellows, only ten of whom are women. Five of these female Fellows have been elected in the past 2 years. Fortunately, BMES now has a Diversity Committee and I strongly hope and suspect that this highly skewed representation will change radically. As I see it the primary issue for women is not being taken seriously either in terms of their recognition or their treatment on the job. One has to ask why women who now make up $35 \%$ of the PhDs in BME comprise only $18 \%$ of the recent faculty hires. This halving of the available pool is true of all science and engineering disciplines and is discussed at length in the 2007 NRC report Beyond Bias and Barriers. For things to change the reward system has to be made more equitable and the academic work place made more family friendly.

Finally, what is true for individuals is also true for entire departments that try to break out of the traditional mold and seriously address the issue of diversity. My department is an obvious case in point. Why is there such a disconnect between the widely accepted metrics of performance cited earlier and the nationally publicized subjective rankings?

\section{ACKNOWLEDGMENTS}

This paper is dedicated to all my $\mathrm{PhD}$ students and in particular to Yuliya Vengrenyuk and Danielle $\mathrm{Wu}$, who were the lead mentors and TA on my NIH Minority Scholars grant for Undergraduate Education. I want to thank Dr. Phillip Payton for his unwavering dedication to all our students and Dr. Mia Ong for her numerous suggestions for the improvement of our Minority Scholars Program. Finally, our Department would not be what it is today without the efforts of all of our faculty and especially our Chair, John Tarbell, who has shared my vision and has helped to make the dream come true. Lastly, I want to recognize the support we have received from NIH, NHBLI, Grant HL 69537, our two infrastructure grants from the Wallace Coulter Foundation, the Whitaker Foundation and the Sloan Foundation. 